\title{
ПОВЫШЕНИЕ ЭФФЕКТИВНОСТИ ПРОИЗВОДСТВА АКРОЛЕИНА НА АО «ВОЛЖСКИЙ ОРГСИНТЕЗ»
}

\author{
В.М. Мохов, С.А. Яковлев
}

Применение акролеина как промежуточного продукта органического синтеза довольно разнообразно. Является сырьем для производства метионина - аминокислотной добавки к кормам в птицеводстве и скотоводстве, мировая потребность в котором оценивается в 450-500 тыс. тонн в год и постоянно возрастает, также как и экспорт акролеина. Статья посвящена совершенствованию стадии синтеза на производстве акролеина АО «Волжский Оргсинтез». Исследовано производство очищенного акролеина на предприятии, где акролеин является полупродуктом и используется для синтеза метилтиопропионового альдегида, из которого затем получают метионин, использующийся в качестве кормовой добавки. Выполнена оценка технико-экономических показателей процесса синтеза акролеина. Выявлены недостатки, затрудняющие эксплуатацию производства. Сформирована основная задача работы - решение проблемы снижения доли побочных продуктов и непрореагировавшего пропилена в реакционном газе. Найден способ повышения технико-экономических показателей химико-технологической системы. Подобран новый катализатор для осуществления синтеза акролеина. Проектное решение одобрено при защите на АО «Волжский Оргсинтез». Выполнен термодинамический анализ реакции получения акролеина. Для способа производства, реализуемого на новом катализаторе, рассчитаны материальный и тепловой балансы, выполнен расчёт реактора.

Ключевые слова: окисление, пропилен, акролеин, метионин, катализаторы, конверсия, селективность, время контакта, термодинамический анализ, реактор.

\section{ВВЕДЕНИЕ}

Акролеин на АО «Волжский Оргсинтез» является полупродуктом и используется для синтеза метилтиопропионового альдегида, из которого затем получают метионин, использующийся в качестве кормовой добавки [1].

Метионин - незаменимая аминокислота, которая принимает участие в синтезе тканевых белков, витаминов, ферментов и гормонов, участвующих в азотистом, углеводном и жировом обменах; является универсальным источником метильных групп для синтеза всех нуклеиновых кислот, а также, источником серы для сульфониевых соединений.

При недостатке метионина в рационах у животных отмечается ухудшение аппетита, анемия, атрофия мускулатуры, нарушение функции печени, снижение скорости роста молодняка и продуктивности животных и птицы.

Метионин кормовой практически полностью усваивается организмом, всасываясь в тонком отделе кишечника [2].

Цель работы - разработка и представление усовершенствований в технологическом процессе синтеза акролеина.

\section{ОПИСАНИЕ ПРОИЗВОДСТВА}

Производство акролеина состоит из трёх основных стадий: синтеза, абсорбции и дистилляции акролеина [3].

Акролеин получают в трубчатом реакторе гетерогенно-катализируемым окислением пропилена в газовой фазе:

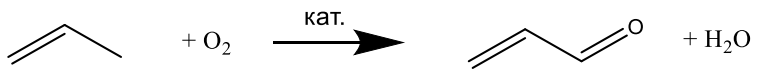

Акролеин образуется при температуре 290-320 들 для повышения конверсии по мере старения катализатора возможно проведение процесса при температурах до $360{ }^{\circ} \mathrm{C}$, но не более, так как при температурах выше $360{ }^{\circ} \mathrm{C}$ преимущественно проходит реакция полного окисления пропилена до диоксида углерода.

Акролеин не является единственным продуктом синтеза (его мольная доля составляет $87,35 \%$ ). Наряду с акролеином в процессе синтеза получаются:

- акриловая кислота (5,04\%);

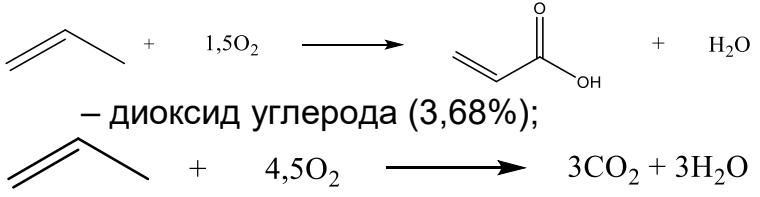




$$
\text { оксид углерода }(2,44 \%) ;
$$

В реакционных газах также могут находиться в «следовых» количествах:

- уксусная кислота;

- ацетон;

- пропионовый альдегид;

- гидропропиональдегид;

- аллиловый спирт;

- малеиновый ангидрид;

- фталевый ангидрид;

- пропиленоксид.

Наличие данных продуктов обусловлено использованием технического пропилена, содержащего примеси - пропан, этилен, ацетилен, метилацетилен.

Часто установки синтеза акролеина являются частью производств акриловой кислоты. В таком случае целевыми являются первые две из приведённых выше реакций, так как на второй стадии акролеин окисляется в акриловую кислоту без предварительного разделения реакционного газа, поступающего с первой стадии. Для получения метионина необходим очищенный акролеин, акриловая кислота здесь является вредным побочным продуктом, требующим отделения. Особенностью установки на АО «Волжский Оргсинтез» является то, что это единственное в России производство очищенного акролеина.

Реакцию получения акролеина проводят при мольном соотношении кислород : пропилен, находящемся в диапазоне 1,28-1,54 и выбираемом в зависимости от текущей активности катализатора.

В настоящее время синтез акролеина проводят путем взаимодействия пропилена с кислородом атмосферного воздуха при разбавлении водяным паром. Реакцию обычно осуществляют в реакторном узле, который состоит из трубчатого реактора, в межтрубном пространстве которого находится хладагент - нитрит-нитратный расплав солей. Хладагент циркулирует через реактор и конструктивно связанный с ним охладитель соли, где тепло реакции снимается с расплава путём испарения котловой воды. После осуществления реакции и охлаждения реакционного газа в кожухотрубном теплообменнике котловой водой реакционный газ подают в колонну резкого охлаждения. Колонна резкого охлаждения - колонна тарельчатого типа, где происходит охлаждение реакционных газов с целью прекращения побочных реакций и абсорбция органических кислот водой [4].

Далее реакционный газ поступает в колонну абсорбции акролеина. Абсорбцию осуществляют путем воздействия оборотной воды на реакционный газ. Процесс проводят в колонне тарельчатого типа. Полученный раствор акролеина подают в колонну стриппинга насадочного типа, работающую под вакуумом, для удаления кислорода и инертных газов. Удаление кислорода важно для предотвращения полимеризации акролеина. После удаления кислорода раствор акролеина подвергается разделению в колонне дистилляции с получением товарного акролеина и воды, отправляемой в узлы промывки реакционного газа от кислот и в колонну абсорбции акролеина.

Таким образом, основной стадией производства акролеина является стадия синтеза. Основными недостатками, усложняющими эксплуатацию производства на $\mathrm{AO}$ «Волжский Оргсинтез» являются потери непрореагировавшего пропилена вследствие недостаточно высокой конверсии $(87,45 \%)$ и наличие кислых сточных вод (акриловая кислота) вследствие недостаточно высокой селективности процесса синтеза $(87,35 \%)$.

\section{ПРАКТИЧЕСКАЯ ЧАСТЬ}

Анализ патентно-технической литературы показал, что данные проблемы решаются заменой используемого катализатора (ACF-2) на катализатор с более высокой заявленной конверсией пропилена и селективностью по основному продукту. Был подобран эффрективный катализатор южнокорейской фрирмы LG Chem. По описанному в патенте на катализатор способу получения акролеина конверсия повышается до 99,5\%, селективность по акролеину составляет 94,4\%. По данному способу требуется повышение мольного соотношения кислород: пропилен до 1,75 [5].

В таблице 1 представлено сравнение технических параметров реализации синтеза на старом и новом катализаторах.

С целью установления принципиальной возможности протекания реакции в прямом направлении и определения тепловой нагрузки на реактор в интервале температур 25-421 ${ }^{\circ} \mathrm{C}(298-694$ К) проведен термодинамический анализ на основе данных [6], результаты которого представлены на рисунках 1-3. 
Таблица 1 - Сравнение параметров способа промышленного аналога и нового способа получения целевого продукта $[3,5]$

\begin{tabular}{|c|c|c|}
\hline Параметр процесса & $\begin{array}{c}\text { Способ производства } \\
\text { аналога }\end{array}$ & Новый способ \\
\hline 1 & 2 & 3 \\
\hline Стадия синтеза & как реализуется & как реализуется \\
\hline Катализатор & ACF-2 $\left(\mathrm{Bi}_{2} \mathrm{O}_{3} \cdot \mathrm{Mo}_{2} \mathrm{O}_{3}\right)$ & LG Chem $\left(\mathrm{Mo}_{a} \mathrm{Bi}_{\mathrm{b}} \mathrm{A}_{c} \mathrm{~B}_{d} \mathrm{C}_{e} \mathrm{O}_{\mathrm{f}}\right)$ \\
\hline Фазовое состояние системы & $\begin{array}{c}\text { Гетерогенный катализ в га- } \\
\text { зовой фазе }\end{array}$ & $\begin{array}{c}\text { Гетерогенный катализ в газо- } \\
\text { вой фазе }\end{array}$ \\
\hline Организация реакторного узла & Трубчатый реактор & Трубчатый реактор \\
\hline Время контакта, с & $2,5-3,5$ & 2,4 \\
\hline Давление процесса, МПа & $0,05-0,1$ & $0,05-0,1$ \\
\hline 1 & 2 & 3 \\
\hline Температура процесса, ${ }^{\circ} \mathrm{C}$ & $290-320$ & 305 \\
\hline $\begin{array}{c}\text { Мольное соотношение реаген- } \\
\text { тов О }: \mathrm{C}_{3} \mathrm{H}_{6}\end{array}$ & $1,28-1,54$ & 1,75 \\
\hline Конверсия, \% & 87,45 & 99,5 \\
\hline $\begin{array}{c}\text { Селективность основной реак- } \\
\text { ции, } \%\end{array}$ & 87,35 & 94,4 \\
\hline Выход по стадии синтеза, \% & 76,39 & 93,93 \\
\hline
\end{tabular}

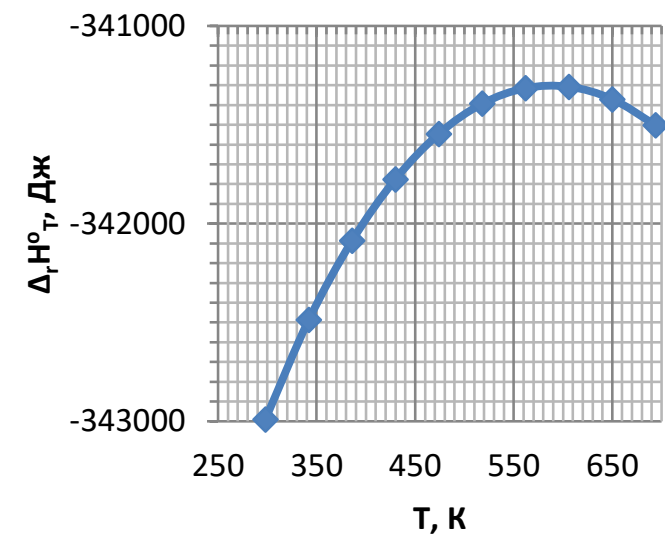

Рисунок 1 - Зависимость изменения теплового эффекта от температуры процесса

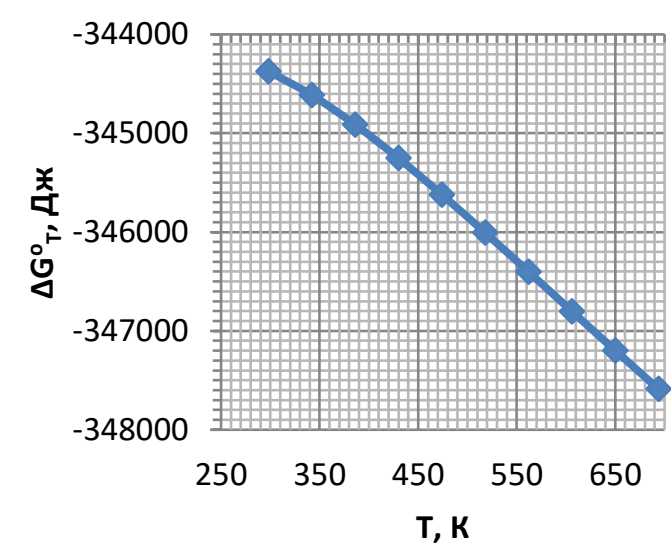

Рисунок 2 - Зависимость изменения энергии Гиббса от температуры процесса

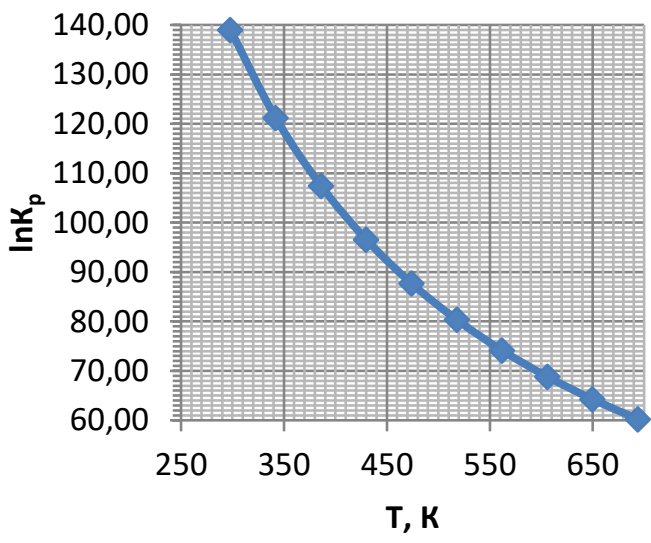

Рисунок 3 - Зависимость натурального логарифма изобарной константы равновесия от температуры

Из анализа термодинамических фуннкций следует, что реакция окисления пропилена в акролеин протекает с выделением теплоты и является сильно экзотермической. По высоким значениям константы равновесия можно сделать вывод, что в интервале температур $25-421{ }^{\circ} \mathrm{C}$ реакция протекает до конца в прямом направлении, то есть с количественным выходом продуктов.

Для реализации процесса в трубчатом реакторе с использованием нового катализатора рассчитан материальный баланс на основе данных [3, 5, 7]. Для обеспечения заданной производительности (10700 т/год товарного акролеина) в реактор надо подавать 
1119,64 кг/ч технического пропилена, 6388,34 кг/ч воздуха и 1070,54 кг/ч водяного пара для получения 1390,76 кг/ч товарного акролеина.

Рассчитан тепловой баланс, согласно которому количество теплоты, которое необходимо отводить от реактора составляет 5717819 кДж/ч.

В соответствии с данными материального и теплового баланса с учётом свойств материалов [8, 9] по методике [10] рассчитан реактор кожухотрубного типа с поверхностью теплообмена $1409 \mathrm{~m}^{2}$, коэффрициентом заполнения трубок 0,91, диаметром труб 30×2,3 мм, высотой 5640 мм, числом труб 4500, диаметром кожуха 2805×7 мм, объемом трубного пространства $6,234 \mathrm{~m}^{3}$. Для достижения необходимого коэффициента заполнения трубок, обеспечивающего расчётную поверхность теплообмена, катализатор разбавляется инертным носителем, в качестве которого предложена керамическая шарообразная насадка.

\section{выводы}

В результате проведенных исследований были предложены усовершенствования производства акролеина на АО «Волжский Оргсинтез», позволяющие сократить объёмы потребляемого сырья при сохранении текущей производительности и уменьшить количество побочных продуктов. Проведён термодинамический анализ процесса синтеза. Рассчитаны размеры предлагаемого реактора и описана схема процесса.

\section{СПИСОК ЛИТЕРАТУРЫ}

1. Winnacker-Kuchler: Chemische Technik / Fifth edition. Vol. 8. Wiley-VCH, Weinheim. 2005. P. 724-727.

2. Инструкция по применению метионина кормового для приготовления премиксов, кормовых смесей и комбикормов для сельскохозяйственных животных и птицы - Волжский : ОАО «Волжский Оргсинтез», 2014. - 2 с.
3. Постоянный технический регламент № 69 производства акролеина - Волжский : ОАО «Волжский Оргсинтез», 2011. - 171 с.

4. Process for the manufacture of acrolein : pat. 9115067 US : IPC C 07 C 45/35 / D.L. Bunning et al. $-2015$.

5. Ring shaped catalyst for producing acrolein and acrylic acid and the use thereof : pat. 101554317 KR : IPC C 07 C 47/22 / H.-S. Lim et al. - 2015.

6. Краткий справочник фризико-химических величин / под ред. А. А. Равделя и А. М. Пономаревой. - Изд. 9-е - Санкт-Петербург : Специальная литература, 1983. - 232 с

7. Справочник химика. В 7 т. Т. 2. Основные свойства неорганических и органических соединений / гл. ред. Б. П. Никольский - 2-е изд., перераб. и доп. - Ленинград : Государственное научнотехническое издательство химической литературы, 1971. - 1168 с.

8. DIN 17175. Seamless steel tubes for elevated temperatures; technical terms of delivery - Berlin, Köln : Beuth Verlag GmbH, 1979.

9. Справочник по теплопроводности жидкостей и газов / Н. Б. Варгафртик [и др.] - Москва : Энергоатомиздат, 1990. - 352 с.

10.Основные процессы и аппараты химической технологии : пособие по проектированию / под ред. Ю. И. Дытнерского - изд. 2-е, перераб. и доп. - Москва : Химия, 1991. - 496 с.

Мохов Владимир Михайлович - к.х.н., доцент кафредры ТОНС, Федеральное государственное бюджетное образовательное учреждение высшего образования Волгоградский государственный технический университет (ФГБОУ ВО ВолаГТУ), Россия, 2. Волгоград, проспект им. Ленина, дом 28, 400005,e-mail:tons@vstu.ru.

Яковлев Сергей Александрович - магистрант ВолгГТУ, Федеральное государственное бюджетное образовательное учреждение высшего образования Волгоградский государственный технический университет (ФГБОУ ВО ВолаГТУ), Россия, 2. Волгоград, проспект им. Ленина, дом 28, 400005, e-mail: sergey.yak2015@yandex.ru. 